Adcreep 
This page intentionally left blank 


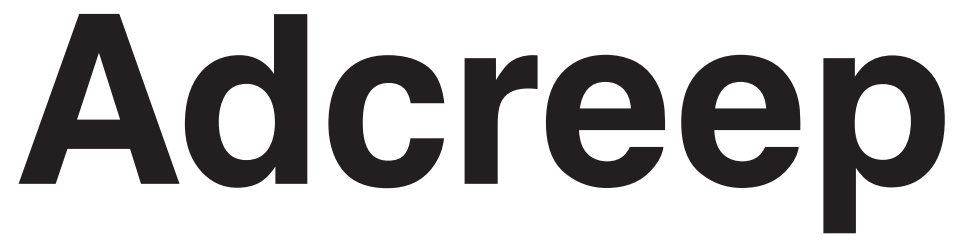

The Case Against Modern Marketing

\section{Mark Bartholomew}

Stanford Law Books

An Imprint of Stanford University Press

Stanford, California 
Stanford University Press

Stanford, California

(C)2017 by the Board of Trustees of the Leland Stanford Junior University. All rights reserved.

No part of this book may be reproduced or transmitted in any form or by any means, electronic or mechanical, including photocopying and recording, or in any information storage or retrieval system without the prior written permission of Stanford University Press.

Printed in the United States of America on acid-free, archival-quality paper

Library of Congress Cataloging-in-Publication Data

Names: Bartholomew, Mark, 1971- author.

Title: Adcreep : the case against modern marketing / Mark Bartholomew.

Description: Stanford, California : Stanford Law Books, an imprint of

Stanford University Press, 2017. | Includes bibliographical references and index.

Identifiers: LCCN 2016040091 (print) | LCCN 2016040663 (ebook) |

ISBN 9780804795814 (cloth : alk. paper) | ISBN 9781503602182 (ebook)

Subjects: LCSH: Advertising laws-United States. | Marketing-Law and

legislation-United States. | Advertising-Social aspects-United States. |

Marketing-Social aspects-United States.

Classification: LCC KF1614 .B37 2017 (print) | LCC KF1614 (ebook) |

DDC $343.7308 / 2-\mathrm{dc} 23$

LC record available at https://lccn.loc.gov/2016040091

Typeset by Bruce Lundquist in 10/15 Minion Pro 
For Hank and Clara 
This page intentionally left blank 